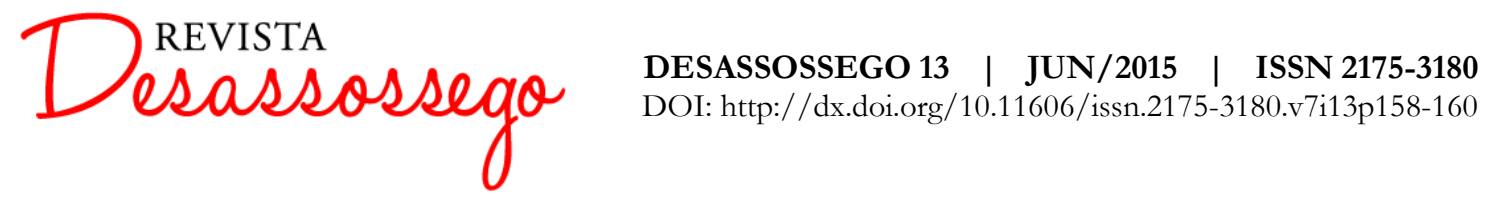

\title{
UM QUADRO NEGRO DE GOYA
}

Diego Felipe Pereira Noleto ${ }^{1}$

Ele cruzou a praça até a Rua Antonino, viu as torres. Ainda era possível reencontrar Denny e a turma, a galera, vez ou outra. Todo mundo reunido no Café Art Bar, nas mesas amarelas da P2. É beber e conversar besta. Agora que não temos mais shows, fiquemos à mercê de birita barata, moscas, chuva e mosquitos - cheirando o dedo. A luz do poste queima muito mosquito sem juízo, atraídos pelo calor, contraste com a chuva, porque aqui não tem onde se proteger. O vinho barato, quando derrama na mesa, gruda e é pegajoso, atrai moscas. A merda é que esse grude suja minha xérox. A vontade é de jogar tudo fora, livrar-me desse peso. Foda-se. É... Foda-se. Enrola baseado, limpa a bunda, faz fogueira.

— Rapaz, ainda ontem mesmo vi o Pedro. De barba, diferente. Agora fala do filho e do emprego. Que nem a mim, a nós.

— Sorte sua, sorte nossa ter vivido o auge disso aqui. Agora que não tem mais Boca... Vamos tomar mais uma?

- E tinha aquele cara... O nome dele como era?

— Tinha uma mochila de urso, dançava pra galera.

- Bicha?

— E eu sei lá!

Da mesa ao lado:

— Thanis. É o Thanis.

Isso! É isso mesmo. Ninguém sabe. Ontem mesmo viram a Joana. Cortou o cabelo. Agora é PM, concurso. Olha todo mundo, cara. As coisas estão bem diferentes agora. Um dia a gente não tinha nada pra beber, quero dizer, birita. Comprar gelada era luxo. Quem diria né, cara? Hoje nós podemos comprar bebida com o dinheiro do nosso trabalho. Hoje podemos tudo, podemos o que não podíamos antes.

${ }^{1}$ Graduado em Letras Português pela Universidade Federal do Piauí (UFPI) e pós-graduando em Literatura, Estudos Culturais e Outras Linguagens pela Universidade Estadual do Piauí (UESPI). 


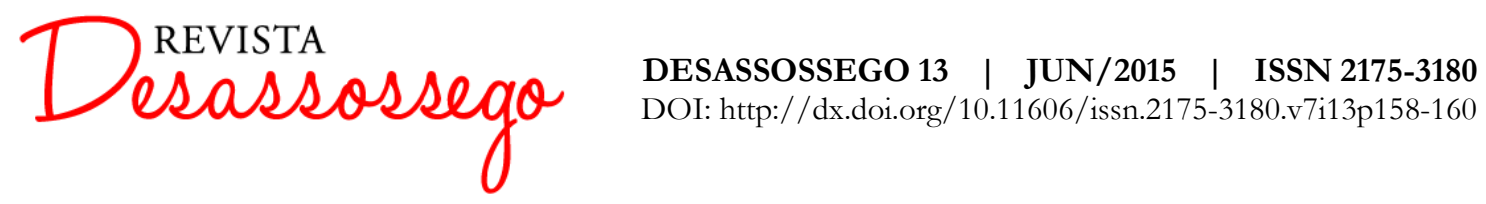

Os Diários ainda abrem as portas para nostálgicos. Os vinis velhos não resistem mais ao tempo, os que persistem nesse ambiente - com cheiro de cerveja choca - são roubados por malandrinhos sem classe, que hoje ocupam as nossas mesas, nossa arquibancada, mas não compartilham da nossa juventude idealizada. Acham que fazem história com suas músicas feias e desconexas. Aqui, onde justamente vivemos o auge da boemia. Eles acham que são os melhores, mas é porque não conheciam o velho Boca. Ficam por aí, falando porcarias e admirando um palco vazio, às vezes com poças d'água. Mas bonito mesmo era o tanque aqui no meio, ó. Nos tempos que o Rex valia a pena. Estivemos nas maiores bilheterias, curtimos mesmo os pornôs.

- Ainda é possível ver o pôr-do-sol pelo lado do Rio Parnaíba. Raios solares que caem por trás de casas abandonadas e prédios deteriorados.

Uma casa de indigentes está à venda por um milhão e meio de reais. Nos tempos de escola era outra coisa, outro tempo mesmo. Hoje é tudo mudado. Não se fazem pastéis como antigamente nem nascem plantas puras como antes. Essas flores estão todas intoxicadas por descargas de carros e fumaças de cigarro. Não mudam mesmo essas pessoas que pitam na frente do Joel, lendo manchetes policiais:

- Menor mata um, menor mata dois e não é preso, rapaz.

- País de lástimas.

- Mendigo toma tiro de tropa.

Respirou ofegante, o sangue a descer, até o fim. A vantagem, única mesmo, de morrer na escada da igreja era porque a alma estava já entregue, a igreja detentora da paz celestial. Raimundo Francisco morreu sem aviso prévio. Todas as outras gentes recebem diagnóstico nas planilhas, médico marcado com antecedência, sempre um psicólogo acompanhando, com a salvação completa do raciocínio. É preciso, isso sim, perceber que o fim se aproxima. Raimundo aceitou a vida porque vivia, simplesmente, sem sentido, dinheiro ou fé.

Os amigos de rua, todos os dias, bebiam olhando aquela cruz exposta a todos que tivessem olhos para ver. Uma cruz de madeira velha, o cupim a comer a fé. Um dorme num banco com o corote perto, o vendedor de Guaraná da Amazônia termina mais cedo o expediente, outros dois olham através do cadáver para mirar uma máquina caça-níqueis do outro lado da rua. 


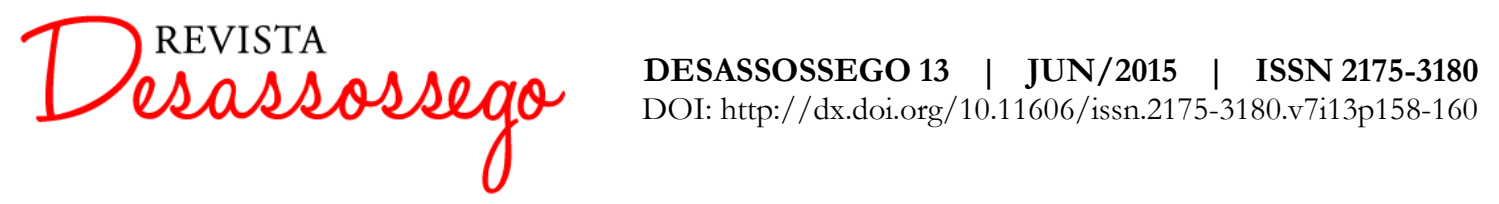

O filete de sangue desce pelos degraus. Onde crianças corriam e senhoras sonhavam com graças, devotos ainda pagam promessas. Os jovens, salientes, miravam calcinhas e xotas, com espelhos amarrados na ponta dos sapatos. Agora recebe uma mancha imaculada daquele homem, agora justo e santo. Mas o sangue já desce e uma mosca assenta no lábio já arroxeado.

Muitos parados na banca leem notícias nacionais e internacionais, que falam dos corruptos na política, roubo de cento e cinquenta milhões de reais e uma guerra religiosa desnecessária. As mães alertam mais sobre roubo do que gravidez. $\mathrm{Na}$ bolsa, as meninas carregam canivetes e não camisinhas. São capazes de matar esses filhos da puta que estupram moças indefesas. A saúde é um caos, educação idem, e o governo que vá...

- Aquele tempo era tempo bom.

Antes, a turma ainda podia andar ao léu, na madrugada, sem incômodo e entrava em festa proibida com identidade do amigo mais velho. Tinha liberdade e espiava na porta do bordel, só para guardar os folhetos do 70 Drink's para se masturbar em casa, debaixo do chuveiro.

- Até prostituta fica velha, sabia?

— A Beth foi presa, mas não perde a pose. Saiu até no jornal.

- Para onde vão todas aquelas raparigas, hein?

— A boate mudou de endereço, velho. Agora é na esquina da praça.

- Outro dia vi a Babalú. É vero que o rosto estava enrugado e os seios bem caídos.

- Mas aquela mulher de quatro não tinha pra ninguém. Lembro-me dos anos vindouros. Olhar ela de costas, aquele rabo, era uma coisa linda. Ela rebolando ainda é um sucesso, um espetáculo.

Atravessou a igreja, ao sol. Visualizou um pequeno potro carregando gente e carga isso ainda, Meu Deus -, que parou para beber uma lama esverdeada, no solo quente do meio-dia. Os sinos da São Benedito tocaram em homenagem e viu a tropa sair em debandada. Uma verdadeira pintura. 